Research Article

\title{
Continuous Adsorption Modeling and Fixed Bed Column Studies: Adsorption of Tannery Wastewater Pollutants Using Beach Sand
}

\author{
Ghita El Mouhri $\mathbb{D}^{1},{ }^{1}$ Mohammed Merzouki, ${ }^{2}$ Hajar Belhassan, ${ }^{2}$ Youssef Miyah, ${ }^{3}$ \\ Halima Amakdouf, ${ }^{2}$ Rabea Elmountassir, ${ }^{1}$ and Anissa Lahrichi ${ }^{1}$ \\ ${ }^{1}$ Laboratory of Biochemistry, Faculty of Medicine and Pharmacy, University Sidi Mohammed Ben Abdellah, Fez, Morocco \\ ${ }^{2}$ Laboratory of Biotechnology, Faculty of Sciences Dhar El Mahraz, P.O. Box 1796, Atlas-Fez, Morocco \\ ${ }^{3}$ Laboratory of Catalysis, Materials and Environment, School of Technology, University Sidi Mohammed Ben Abdellah, \\ $\mathrm{Fez}, \mathrm{Morocco}$
}

Correspondence should be addressed to Ghita El Mouhri; elm.ghita@gmail.com

Received 17 October 2019; Revised 17 December 2019; Accepted 19 December 2019; Published 24 January 2020

Guest Editor: Mohamed R. Berber

Copyright (c) 2020 Ghita El mouhri et al. This is an open access article distributed under the Creative Commons Attribution License, which permits unrestricted use, distribution, and reproduction in any medium, provided the original work is properly cited.

\begin{abstract}
This study deals with the removal of residual pollutants from tanning wastewater by continuous adsorption mechanism, using local sand as a low-cost adsorbent. The possibility of pretreating a complex tannery effluent heavily loaded with a natural material such as sand is significant. The characterization of the adsorbent before and after continuous adsorption was performed by X-ray diffraction, Fourier transform infrared spectroscopy, and scanning electron microscopy. Column studies were also carried out to evaluate the performance of the adsorbent and the efficiency of column adsorption. The adsorption kinetic rate seems to be strongly influenced by certain parameters such as the particle size of the material used, the withdrawal rate of the influent and the height of the adsorbent bed, and optimized parameters were found to be $63 \mu \mathrm{m}, 15 \mathrm{ml} \cdot \mathrm{min}^{-1}$, and $7 \mathrm{~cm}$, respectively, and the color removal has achieved maximum values which vary between 95 and $100 \%$. The results suggest that sand can be used as an economical adsorbent for the removal of color from the wastewater of the tanning industries.
\end{abstract}

\section{Introduction}

Industrial tanning is one of the most important sectors in Morocco's economy [1]. Consequently, the consumption of huge quantities of water during all leather processing operations and the discharge of untreated effluents leads to very serious problems, particularly on water quality and human health, and makes it one of the main polluters that influence the ecological balance negatively [2-5].

Both scientists and health authorities have spent the effort considered in pollution clean-up and prevention $[3,5,6]$. Many types of treatment systems have been considered to eliminate heavy metal contamination in the environment [7-9], including ion exchange, flocculation, coagulation, chemical oxidation, chemical precipitation, ozonation, membrane filtration, electrochemical filtration, and activated carbon adsorption [10-15]. However, the main limiting factors against the use of these processes are high operational costs, low disposal efficiency, generation of toxic byproducts and sludge, and difficulty of implementation and time $[11,16]$.

Among the different processes for purifying effluents loaded with heavy metals, adsorption, which involves fixing the pollutant load at the interface through physical or chemical bonds, offers better performance and fewer problems compared with other advanced processes $[17,18]$. Adsorption also offers an economical solution by developing sorbents with a much lower cost [18-22].

In this study, the use of continuous adsorption was chosen for the treatment of larger volumes and to remove as 
many pollutants as possible from the tannery effluent. Preliminary experimental studies were conducted to understand the general mechanism of adsorption, the different characteristics and limitations in column design. Adsorption was designed in continuous mode by percolating effluents through fixed bed columns with detailed kinetic modeling to evaluate the variation in some operating parameters such as granulometry, adsorbent bed height, and influent withdrawal rate.

\section{Materials and Methods}

2.1. Materials. The effluent from the tannery's activity was collected from an industrial unit located in the Dokkarat district of Fez and stored at a temperature of $4^{\circ} \mathrm{C}$ until use. The adsorbent material used is sand from a Moroccan beach, and this adsorbent has undergone several rinses with ultrapure water until the removal of residues and neutralization of the $\mathrm{pH}$. It is then dried in an oven overnight at $80^{\circ} \mathrm{C}$ for total removal of water, ground, and sieved to obtain a fraction in the range of $63-80 \mu \mathrm{m}$ in diameter $[3,18,23]$. The physicochemical characteristics of the tannery effluent are shown in Table 1.

2.2. Instrumental Analysis. The granulometric curve of the sand and the simple percentages (\%) of each granular fraction were established using a vibrating sieve shaker (RETSCH AS 200) [24], and the crystalline structure of the sand powder was analyzed by X-ray diffractometry (Diffractometer X'Pert PRO); the Fourier transform infrared spectroscopy was carried out to study the particular types of chemical bonds and groups existing in the sample, and morphological analysis of the sand before and after saturation by effluent components was performed by scanning electron microscope, equipped with an X-ray energy dispersion spectrometer (EDX).

2.3. Adsorption Studies in a Continuous System. The treatment of the tannery effluent was carried out with an experimental system made of a glass column, with a dimension of $3 \mathrm{~cm}$ in inner diameter and $50 \mathrm{~cm}$ in height. The sand bed was packed into the column and wetted with ultrapure water to release the trapped air between the particles. Tannery wastewater was continuously supplied through the column using a peristaltic pump. Every 10 minutes, the treated influent was collected, and the optimal parameters were selected using a spectrophotometer (UV-Visible BioSpec-mini) at a maximum wavelength $(\lambda \max )$ of $400 \mathrm{~nm}$ Figure 1.

2.3.1. Effect of Sand Granulometry. To evaluate the effect of particle size, five sand fractions were varied at different diameters: $63,125,200,315$, and $400 \mu \mathrm{m}$. These granular fractions were filled into separate columns to form compacted beds with a height of $5 \mathrm{~cm}$. The withdrawal flow rate has been set at $15 \mathrm{ml} \cdot \mathrm{min}^{-1}$.
TABle 1: Physicochemical characteristics of real tannery wastewater.

\begin{tabular}{lc}
\hline Parameter & Values \\
\hline $\mathrm{pH}$ & 6,25 \\
Temperature $\left({ }^{\circ} \mathrm{C}\right)$ & 25 \\
Electrical conductivity $\left(\mu \mathrm{s} \cdot \mathrm{cm}^{-1}\right)$ & 10900 \\
COD $\left(\mathrm{mg} \cdot \mathrm{L}^{-1}\right)$ & 11800 \\
BOD5 $\left(\mathrm{mg} \cdot \mathrm{L}^{-1}\right)$ & 1200 \\
Total chromium $\left(\mathrm{mg} \cdot \mathrm{L}^{-1}\right)$ & 32,2 \\
Color & Dark blue \\
\hline
\end{tabular}

2.3.2. Effect of the Withdrawal Rate. To choose the most appropriate withdrawal rate for the treatment of tannery effluent, we opted for a grain size of $63 \mu \mathrm{m}$ in diameter, a compacted bed of $3 \mathrm{~cm}$ in height, and adjusted the withdrawal rates of the influents to values of $15,65,115$, and $170 \mathrm{ml} \cdot \mathrm{min}^{-1}$.

2.3.3. Effect of the Adsorbent Bed Height. After the determination of the two parameters: grain size and flow rate, the effect of filter bed height on the rate of discolouration was studied to determine which one provides better continuous adsorption. And, for this, the sand beds were varied according to different masses, namely, 20.2, 36, and $50 \mathrm{~g}$, and the heights of the sand beds were measured at 3,5 , and $7 \mathrm{~cm}$, respectively.

\section{Results and Discussion}

3.1. Particle Size Curve of Sand. The descriptive percentages of the granulometric analyses are illustrated in Figure 2; the figure shows the allocation of 7 fractions for the granulometric distribution of sand, and the preponderant size which predominates is $200 \mu \mathrm{m}$ with a percentage of $61.5 \%$. This size is less than $500 \mu \mathrm{m}$, which gives it the class of fine sands.

3.2. X-Ray Diffraction. The crystalline composition of the sand particles before and after adsorption is shown in Figure 3. The X-ray diffractograms of the sand before and after adsorption shows almost the same appearance and reveal the existence of several characteristic peaks of quartz and calcite $[25,26]$. For unsaturated sand, these two elements have a codominance indicated by the major peaks corresponding to the position $2 \theta, 27.7^{\circ}$ and $29.7^{\circ}$, respectively [27-31]. Whereas for saturated sand, quartz predominates over calcite with the appearance of two unidentified peaks at $2 \theta, 43.41^{\circ}$ and $51.08^{\circ}$, which can be attributed to the effluent components of the tannery.

3.3. Infrared Spectroscopy Analysis. Figure 4 and Table 2 present the main functional groups of the specific elements of natural sand and the possible modifications after the adsorption process. On one hand, the examination of these results show no change in the basic structure of Lowded Sand (LS) particles and this allows us to say that adsorption is done by physical interaction forces [25]. On other hand, the maximum intensities have decreased slightly; this may be related to an energy variation due to the bonds established 


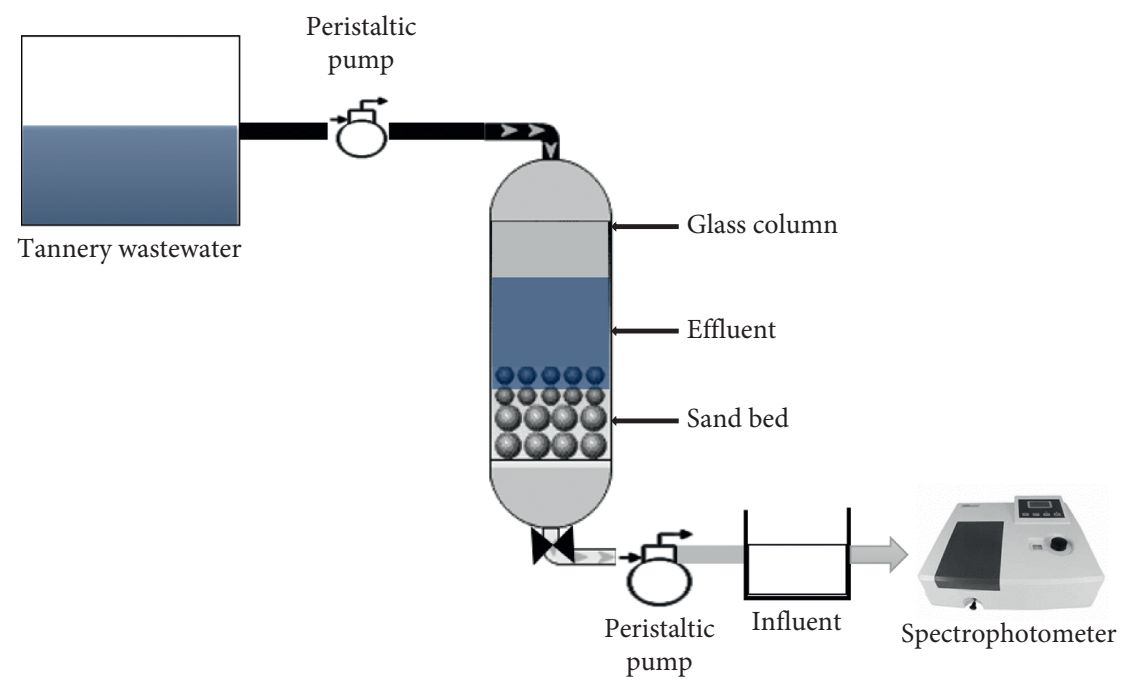

Figure 1: Experimental device.

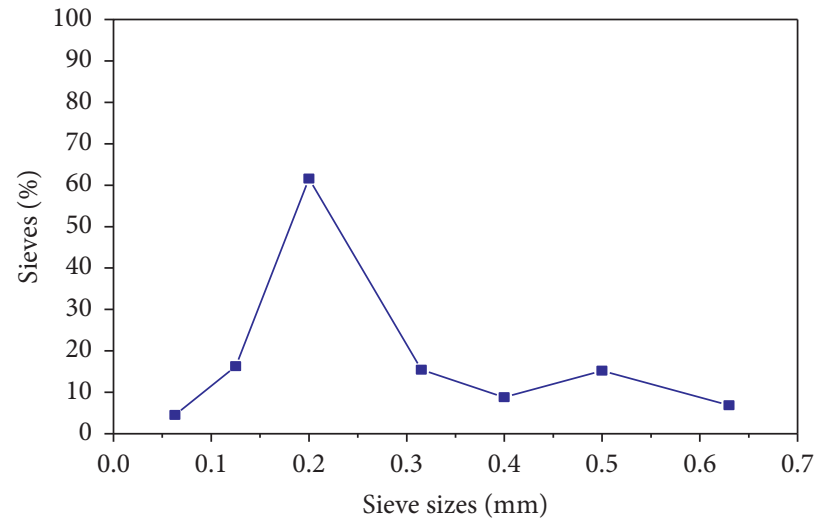

Figure 2: Granulometric curve of the sand used.

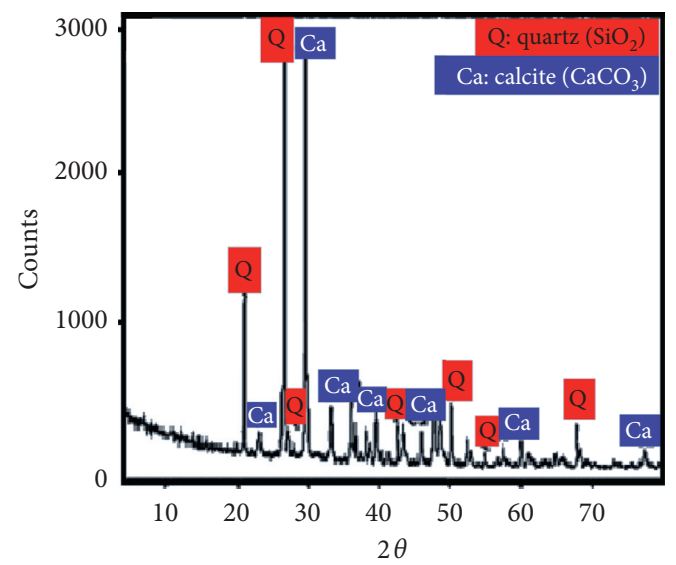

(a)

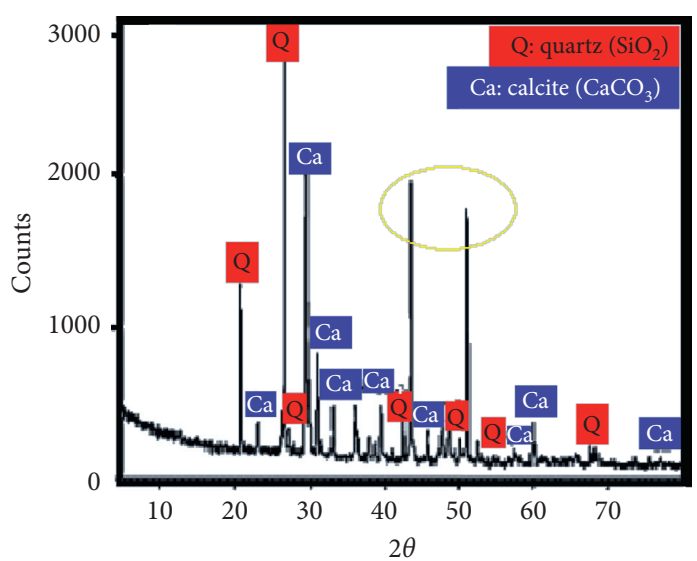

(b)

FIgure 3: Diffractometric analysis of (a) natural sand and (b) loaded sand.

with the pollutants in the effluent, and a small shift has been observed in the position of the adsorption bands, which probably justifies the feasibility of adsorption [18].
These results also confirm the existence of the bonds characterizing calcite and quartz previously revealed by diffractometric analysis. 


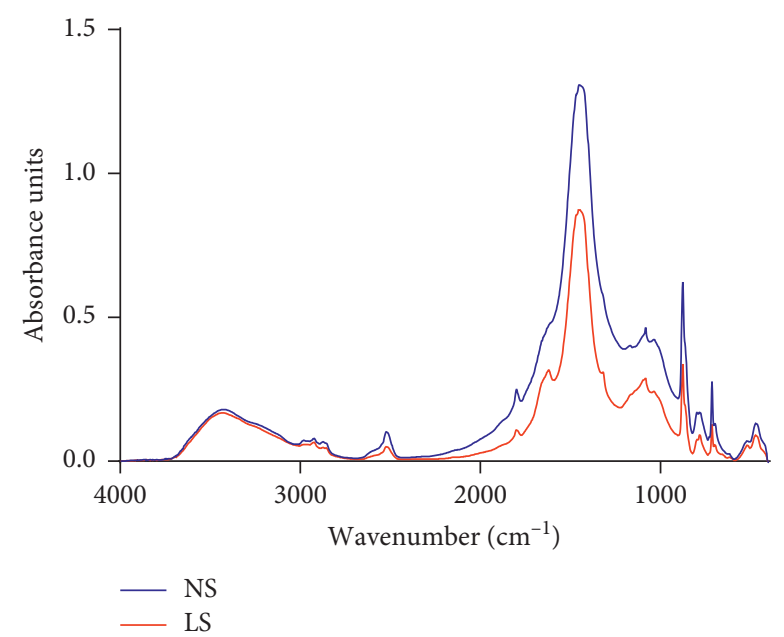

FIgURE 4: Infrared spectrum of natural sand (NS) and loaded sand (LS).

TABLE 2: Sand infrared bands and their assignments.

\begin{tabular}{|c|c|c|c|}
\hline Natural sand position $\left(\mathrm{cm}^{-1}\right)$ & Loaded sand position $\left(\mathrm{cm}^{-1}\right)$ & Assignments & Reference \\
\hline 3419.60 & 3427.62 & $\mathrm{OH}$ group stretch vibration & {$[18,32,33]$} \\
\hline 2922.88 & 2924.36 & $\mathrm{C}-\mathrm{H}$ asymmetrical stretching vibrations & {$[25,32,34]$} \\
\hline 2519.05 & 2518.98 & $\mathrm{C}-\mathrm{H}$ asymmetrical stretching vibration & [25] \\
\hline 1797.17 & 1796.91 & Typical vibration of the $\mathrm{OH}$ stretching group & {$[3]$} \\
\hline - & 1620.91 & $\mathrm{OH}$ group stretch vibration & {$[18]$} \\
\hline 1450.90 & 1452.76 & $\mathrm{CO}_{3}$ stretching of calcite & {$[3,35]$} \\
\hline 1082.85 & 1083.32 & Valence vibration of the $\mathrm{Si}-\mathrm{O}-\mathrm{Si}$ bond & {$[18,23,32]$} \\
\hline 874.56 & 874.60 & $\mathrm{CO}_{3}$ stretching of calcite & [35] \\
\hline 779.91 & 780.64 & $\mathrm{O}-\mathrm{Si}-\mathrm{O}$ stretching & {$[25]$} \\
\hline 712.48 & 712.55 & $\mathrm{O}-\mathrm{Si}-\mathrm{O}$ stretching & {$[25]$} \\
\hline 469.17 & 469.92 & Valence vibration of the $\mathrm{Si}-\mathrm{O}-\mathrm{Si}$ bond & {$[25]$} \\
\hline
\end{tabular}

3.4. Scanning Electron Microscopy Coupled with the EDX. The SEM results coupled with the EDX of the sand before and after saturation as well as the mass percentages of each element are shown in Figure 5 and Table 3. The internal microstructure of unmodified sands shows a rough, irregular, and proportionally porous and cracked appearance with the presence of some luminous and relatively ordered aggregations, that probably indicate the existence of quartz crystals previously detected by the DRX analysis [18, 36]. This mineralogical composition allows the interchanges of substances with adjacent cells and thus makes the adsorption mechanism possible (Figure 5(a)).

Microstructural analysis reveals significant changes in the surface morphology of the sand after adsorption of the effluent. We notice the formation of a dense and compact matrix with a decrease in the degree of porosity and luminosity, and this can be explained by the adsorption of the molecules contained in the treated solute on the sand cracks and pores (Figure 5(b)) [18].

The chemical analysis by EDX proves the validity of spectral analysis with regard to the chemical composition of the sand used and shows that it consists mainly of $\mathrm{C}, \mathrm{O}, \mathrm{Ca}$, and $\mathrm{Si}$. The results also indicate the appearance of certain elements involved in the chemical composition of tannery effluent such as nitrogen, sulfur, chlorine, and chromium. The mass percentage of some elements such as $\mathrm{O}, \mathrm{Mg}, \mathrm{Si}, \mathrm{Fe}$, and $\mathrm{Na}$ decreased slightly after adsorption; this leads us to suppose that they were involved in the adsorption process of the effluent components Table 3 and Figure 5.

\subsection{Column Experiments}

3.5.1. Effect of Sand Grain Size on Effluent Discolouration. Figure 6 shows the tannery effluent discolouration kinetics that have been studied for the different grain sizes of sand powder from $63 \mu \mathrm{m}$ to $400 \mu \mathrm{m}$.

The results show that the highest rate of discolouration is represented by the preponderant size of $63 \mu \mathrm{m}$, and discolouration decreases with the increase in the diameter of the sand particles. The graphical presentation also shows that the fading rate is optimal and provides total fading of $100 \%$ for the $63 \mu \mathrm{m}$ grain size, while the fading rate does not exceed $82 \%$ for the $400 \mu \mathrm{m}$ grain size. The discolouration rates for the $125 \mu \mathrm{m}, 200 \mu \mathrm{m}$, and $315 \mu \mathrm{m}$ particle sizes are $97.2 \%, 94.4 \%$, and $93.61 \%$, respectively. As a conclusion, it can be said that the particle size is an important factor, which affects the adsorption capacity, and the fixation of the organic matter on the surface of the adsorbent material is 


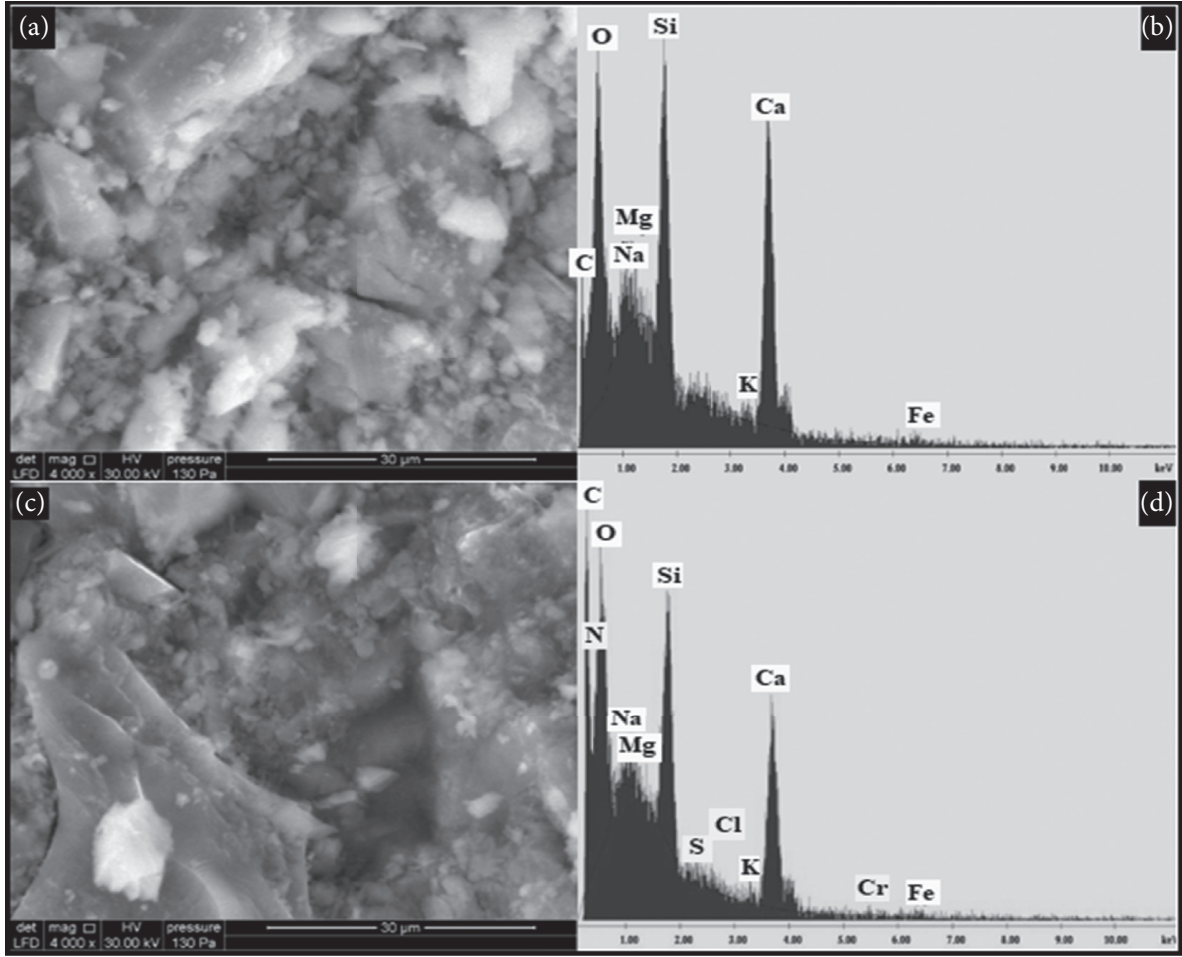

Figure 5: Morphological examination of natural sand ( $a, b)$ and loaded sand $(c, d)$ by SEM-EDX.

TABle 3: Percentage of elements found by X-ray energy dispersion EDX in natural and loaded sand.

\begin{tabular}{lcc}
\hline Elements & Natural sand (NS) & Loaded sand (LS) \\
\hline $\mathrm{C}$ & 26.34 & 32.05 \\
$\mathrm{O}$ & 46.18 & 18.12 \\
$\mathrm{~N}$ & - & 34.55 \\
$\mathrm{Na}$ & 3.42 & 1.45 \\
$\mathrm{Mg}$ & 0.94 & 0.45 \\
$\mathrm{Si}$ & 8.66 & 5.36 \\
$\mathrm{~S}$ & - & 0.40 \\
$\mathrm{Cl}$ & - & 0.43 \\
$\mathrm{~K}$ & 0.54 & 0.37 \\
$\mathrm{Ca}$ & 12.63 & 5.98 \\
$\mathrm{Cr}$ & - & 0.27 \\
$\mathrm{Fe}$ & 1.3 & 0.58 \\
Total & 100 & 100 \\
\hline
\end{tabular}

generally more important when the grain size of the material is small [37].

The studies of Sakr et al. conducted on the adsorption of methylene blue on cactus found similar results to those of our study with regard to the effect of particle size, and the highest percentages of adsorption were obtained using a size of $0.04 \mathrm{~mm}$ of cactus [38]. And, according to Guiza and Bagane who have worked with bentonite for the adsorption of Congo Red; an increase in particle diameter leads to a decrease in the transfer rate of the material [39].

3.5.2. Effect of Flow Rate on Effluent Discolouration. The experimental results shown in Figure 7 show that the

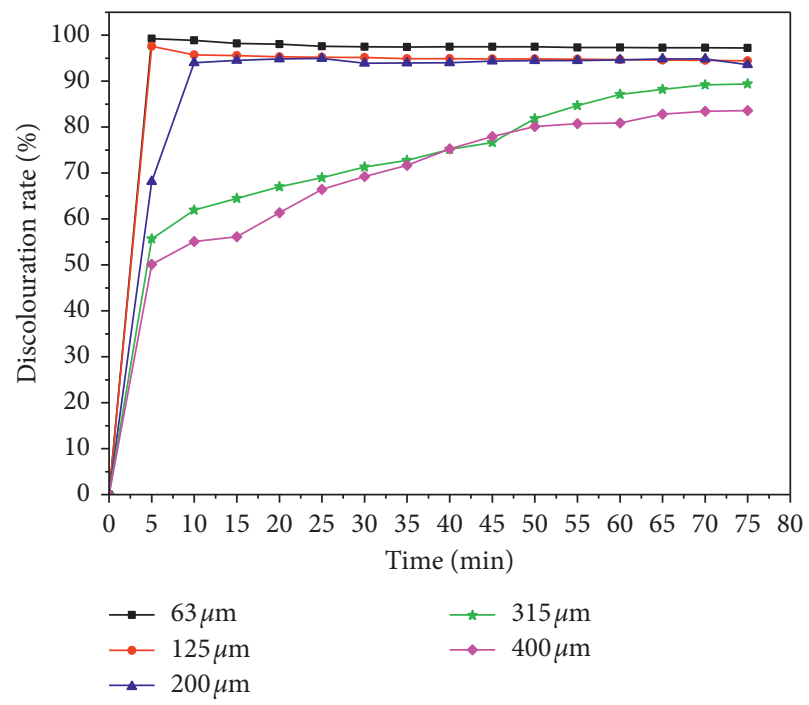

FIGURE 6: Effect of sand grain size on the discolouration rate.

discolouration capacity of the tannery effluent by sand is proportionally inverse to the withdrawal rate.

The rate of discolouration is maximum with a value of $95.6 \%$ for low flow which is equal to $15 \mathrm{ml} \cdot \mathrm{min}^{-1}$ and minimum with a value of $90.4 \%$ for flow increased to $170 \mathrm{ml} \cdot \mathrm{min}^{-1}$. From the results, it can be seen that the increase in the withdrawal rate causes a decrease in the residence time of the effluent molecules in the column. Thus, the exchange speed decreases, resulting in a loss of adsorption efficiency. Experimentally, the increase in flow rate 


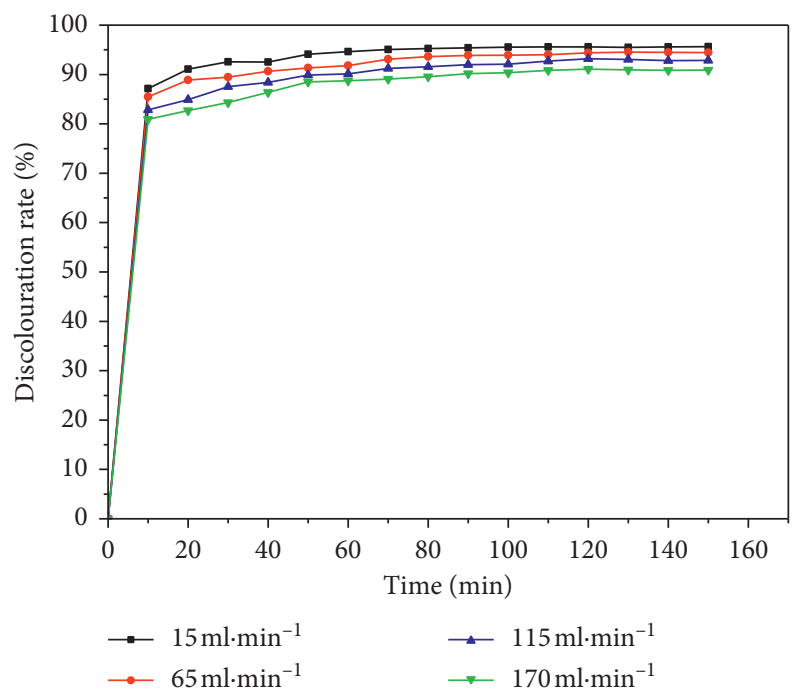

Figure 7: Effect of the withdrawal rate on the discolouration rate.

causes a rapid saturation of the filter bed, and this is due to the increase in the exchange speed.

Research carried out by Biswas and Mishra has also found that an increase in the withdrawal rate reduces the adsorbent-adsorbate contact time [40]. And, according to Sathvika et al., low flows increase the adsorption efficiency and increase the contact time between chromium VI solution and the biosorbent used [41].

\subsubsection{Effect of Filter Bed Height on Effluent Discolouration.}

Figure 8 shows the effect of sand bed height on the rate of effluent discolouration. The results show that the total adsorption capacity increases with increasing bed height. The $3 \mathrm{~cm}$ and $5 \mathrm{~cm}$ beds have discolouration rates of $95.4 \%$ and $97.4 \%$, respectively. The maximum fading rate is given by the $7 \mathrm{~cm}$ bed with a percentage that is close to $100 \%$. From these results, it can be deduced that the height of the bed through which the effluent passes is one of the parameters that influence the performance of continuous adsorption and the operation of the column. The amount of adsorbent material used affects significantly the residence time, discolouration rate and volume of the treated effluent. The contact time becomes shorter as the height of the adsorbent bed decreases. This indicates that the bed with the minimum height of $3 \mathrm{~cm}$ is saturating faster. Whereas increasing the height of the adsorbent to $7 \mathrm{~cm}$ slows down the rate of solute-solid exchange and thus increases the residence time and improves the availability of active adsorption sites, which quantitatively and qualitatively promotes the retention of pollutants present in the tannery effluent [42].

Similar results were found by Lim and Aris who showed that the adsorption of $\mathrm{CD}$ (II) and $\mathrm{Pb}$ (II) is higher for the longest bed of the dead limestone skeletons and which is $2.20 \mathrm{~cm}$ equivalent of $40 \mathrm{~g}$ [8]. In another study conducted by (Tsai et al.), the results showed that the increase in the height of the activated carbon bed leads to a decrease in the

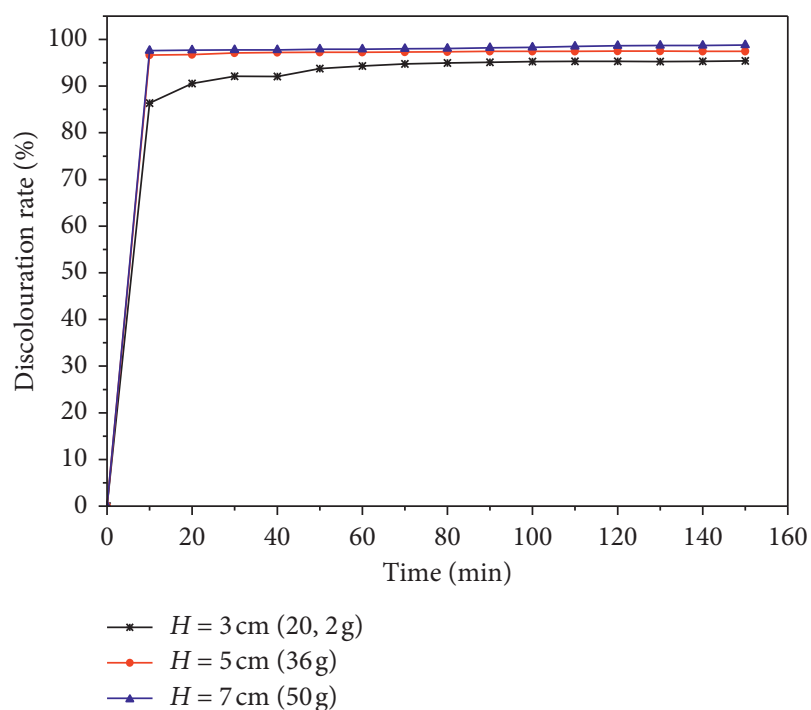

Figure 8: Effect of the sand bed height on the discolouration rate.

concentration of $\mathrm{Pb}$ (II), $\mathrm{Cu}$ (II), and $\mathrm{Ni}$ (II) in the influent [43].

3.5.4. Visual Appearance of the Raw Effluent and the Adsorbates. The visual appearance and reduction of the coloration of the raw effluent from the tannery (A0, B0, and $\mathrm{C} 0$ ) according to the different effects are shown in Figure 9. These results show that the adsorbates (A1, A2, A3, and A4) have a slight coloration compared with the raw effluent $\mathrm{A} 0$, and this coloration decreases as the size of the sand grains decreases until an almost colourless influent is obtained (A5) (Figure 9(a)). The visual aspect of the adsorbates obtained at different flow rates (B1, B2, and B3) also show increasing discolouration with the decrease in the withdrawal rate Figure 9(b). For the effect of the height of the adsorbent bed, 

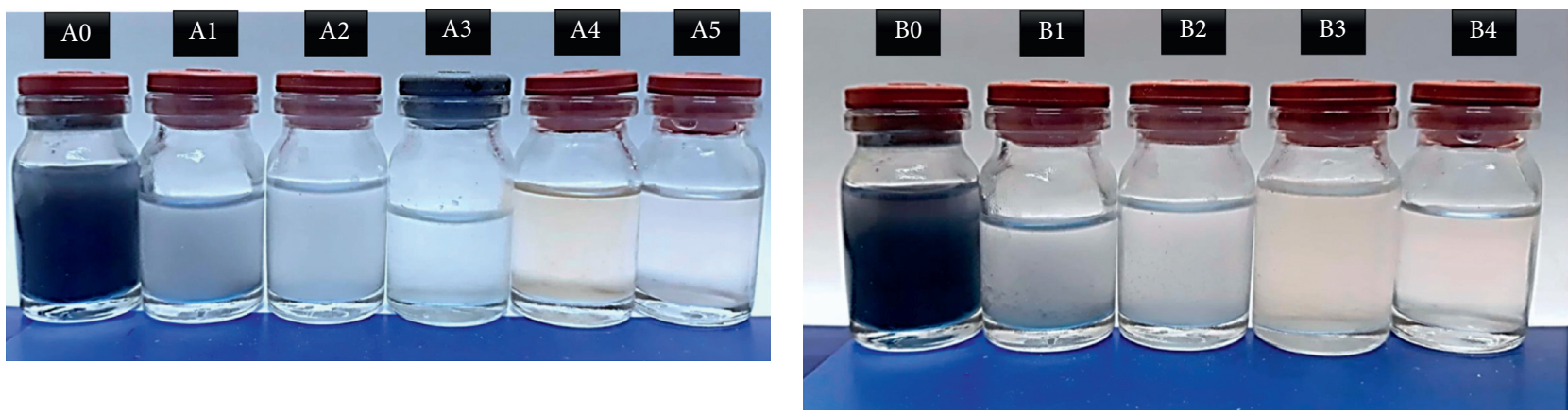

(a)

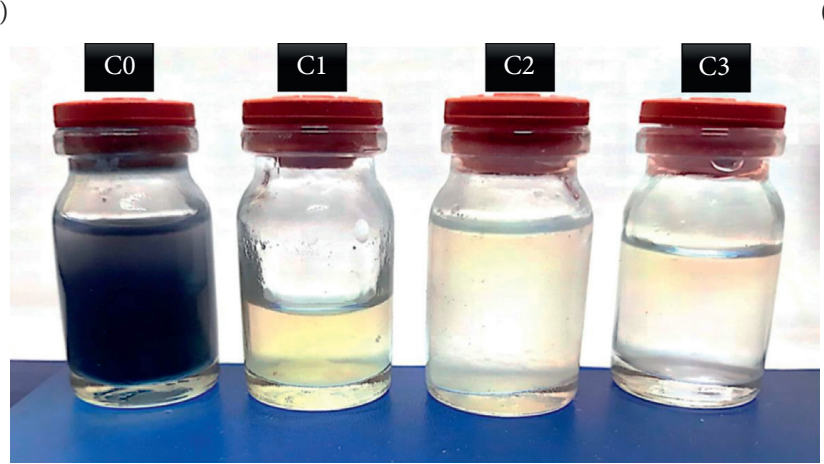

(b)

(c)

FIGURE 9: Visual appearance of the raw effluent and the adsorbates obtained according to the different effects.

we notice that, from a dark blue effluent $\mathrm{C} 0$, we obtain translucent adsorbates with a slightly yellowish coloration for C1, while C3 and C4 have practically the same aspect as indicated by the graphical data (Figure $9(\mathrm{c})$ ).

\section{Conclusion}

The treatment of effluent from tanning activity by a biological process appears to be difficult, as it is highly loaded with heavy metals and has a toxic environment for microbial biomasses. This study proved the effectiveness of marine sands in cleaning up industrial tanning water and removing micropollutants as a pretreatment step. Experimental tests show that the discolouration rate is optimal and close to $100 \%$ for the sand grain size of $63 \mu \mathrm{m}$. The rate of discolouration is maximum with a value of $95.6 \%$ for the low flow rate which is equal to $15 \mathrm{ml} \cdot \mathrm{min}^{-1}$. The maximum fading rate is given by the $7 \mathrm{~cm}$ sand bed with a value of $98.7 \%$.

The characterization of the sand by the different FTIR, SEM, and X-RD techniques has revealed modifications in the surface as well as the crystalline and chemical structure of the sand after adsorption which means the retention of effluent pollutants through pores and cracks in marine sand.

\section{Data Availability}

The data used to support the findings of this study are available from the corresponding author upon request.

\section{Conflicts of Interest}

The authors declare that they have no conflicts of interest.

\section{References}

[1] Y. Metarfi, K. El Rhazi, F. Z. El Madani, A. Omor, and Z. Rais, "Risques professionnels liés à la manipulation du chrome au sein des tanneries modernes de la ville de Fès, Maroc," Revue d'Épidémiologie et de Santé Publique, vol. 66, p. S187, 2018.

[2] S. Elabbas, N. Ouazzani, L. Mandi et al., "Treatment of highly concentrated tannery wastewater using electrocoagulation: influence of the quality of aluminium used for the electrode," Journal of Hazardous Materials, vol. 319, pp. 69-77, 2016.

[3] G. El Mouhri, M. Merzouki, Y. Miyah et al., "Valorization of two biological materials in the treatment of tannery effluents by filtration treatment of tannery effluents by filtration," Moroccan Journal of Chemistry, vol. 7, pp. 183-193, 2019.

[4] S. Ramírez, G. Torrealba, E. Lameda-Cuicas, L. MolinaQuintero, A. I. Stefanakis, and M. C. Pire-Sierra, "Investigation of pilot-scale constructed wetlands treating simulated pre-treated tannery wastewater under tropical climate," Chemosphere, vol. 234, pp. 496-504, 2019.

[5] M. N. Hairuddin, N. M. Mubarak, M. Khalid, E. C. Abdullah, R. Walvekar, and R. R. Karri, "Magnetic palm kernel biochar potential route for phenol removal from wastewater," Environmental Science and Pollution Research, vol. 26, no. 34, pp. 35183-35197, 2019.

[6] J. L. Perrin, N. Raïs, N. Chahinian, P. Moulin, and M. Ijjaali, "Water quality assessment of highly polluted rivers in a semiarid Mediterranean zone Oued Fez and Sebou River (Morocco)," Journal of Hydrology, vol. 510, pp. 26-34, 2014.

[7] R. R. Karri and J. N. Sahu, "Modeling and optimization by particle swarm embedded neural network for adsorption of zinc (II) by palm kernel shell based activated carbon from aqueous environment," Journal of Environmental Management, vol. 206, pp. 178-191, 2018. 
[8] A. P. Lim and A. Z. Aris, "Continuous fixed-bed column study and adsorption modeling: removal of cadmium (II) and lead (II) ions in aqueous solution by dead calcareous skeletons," Biochemical Engineering Journal, vol. 87, pp. 50-61, 2014.

[9] R. R. Karri, J. N. Sahu, and B. C. Meikap, "Improving efficacy of $\mathrm{Cr}(\mathrm{VI})$ adsorption process on sustainable adsorbent derived from waste biomass (sugarcane bagasse) with help of ant colony optimization," Industrial Crops and Products, vol. 143, Article ID 111927, 2020.

[10] S. Boumchita, A. Lahrichi, Y. Benjelloun, S. Lairini, V. Nenov, and F. Zerrouq, "Application of peanut shell as a low-cost adsorbent for the removal of anionic dye from aqueous solutions," Journal of Materials and Environmental Science, vol. 8, pp. 2353-2364, 2017.

[11] M. Liu, X. Li, Y. Du, and R. Han, "Adsorption of methyl blue from solution using walnut shell and reuse in a secondary adsorption for Congo red," Bioresource Technology Reports, vol. 5, pp. 238-242, 2019.

[12] H. N. Bhatti, A. Jabeen, M. Iqbal, S. Noreen, and Z. Naseem, "Adsorptive behavior of rice bran-based composites for malachite green dye: isotherm, kinetic and thermodynamic studies," Journal of Molecular Liquids, vol. 237, pp. 322-333, 2017.

[13] M. T. Yagub, T. K. Sen, S. Afroze, and H. M. Ang, "Dye and its removal from aqueous solution by adsorption: a review," Advances in Colloid and Interface Science, vol. 209, pp. 172184, 2014.

[14] R. R. Karri, J. N. Sahu, and N. S. Jayakumar, "Optimal isotherm parameters for phenol adsorption from aqueous solutions onto coconut shell based activated carbon: error analysis of linear and non-linear methods," Journal of the Taiwan Institute of Chemical Engineers, vol. 80, pp. 472-487, 2017.

[15] R. R. Karri, N. S. Jayakumar, and J. N. Sahu, "Modelling of fluidised-bed reactor by differential evolution optimization for phenol removal using coconut shells based activated carbon," Journal of Molecular Liquids, vol. 231, pp. 249-262, 2017.

[16] Y. Benjelloun, A. Lahrichi, S Boumchita et al., "Removal of crystal violet by wet oxidation with $\mathrm{H}_{2} \mathrm{O}_{2}$ over an iron oxide catalyst synthesized from fly ash," Journal of Materials and Environmental Science, vol. 8, pp. 2259-2269, 2017.

[17] A. Fegousse, A. El Gaidoumi, Y. Miyah, R. E. Mountassir, and A. Lahrichi, "Pineapple bark performance in dyes adsorption: optimization by the central composite design," Journal of Chemistry, vol. 2019, Article ID 3017163, 11 pages, 2019.

[18] A. Sharma, Z. Syed, U. Brighu, A. B. Gupta, and C. Ram, "Adsorption of textile wastewater on alkali-activated sand," Journal of Cleaner Production, vol. 220, pp. 23-32, 2019.

[19] M. Mirzaeinejad, Y. Mansoori, and M. Amiri, "Amino functionalized ATRP-prepared polyacrylamide-g-magnetite nanoparticles for the effective removal of $\mathrm{Cu}(\mathrm{II})$ ions: kinetics investigations," Materials Chemistry and Physics, vol. 205, pp. 195-205, 2018.

[20] Y. Cui and J. D. Atkinson, "Ultrasonic spray pyrolysis synthesis of nitrogen-doped porous $\mathrm{Fe} / \mathrm{C}$ composites from glycerol for hexavalent chromium removal," Materials Chemistry and Physics, vol. 221, pp. 29-33, 2019.

[21] M. Ghaedi, S. Hajjati, Z. Mahmudi et al., "Modeling of competitive ultrasonic assisted removal of the dyesmethylene blue and Safranin-O using $\mathrm{Fe}_{3} \mathrm{O}_{4}$ nanoparticles," Chemical Engineering Journal, vol. 268, pp. 28-37, 2015.

[22] Y. Miyah, A. Lahrichi, M. Idrissi, A. Khalil, and F. Zerrouq, "Adsorption of methylene blue dye from aqueous solutions onto walnut shells powder: equilibrium and kinetic studies," Surfaces and Interfaces, vol. 11, pp. 74-81, 2018.

[23] V. Khatibikamal, A. Torabian, H. Ahmad panahi, and M. Baghdadi, "Stabilizing of poly(amidoamine) dendrimer on the surface of sand for the removal of nonylphenol from water: batch and column studies," Journal of Hazardous Materials, vol. 367, pp. 357-364, 2019.

[24] K. B. Amey, K. Neglo, S. Tamba, A. Kodjo, and C. Johnson, "Caractérisation physique de sables silteux au Togo," Afrique Science: Revue Internationale des Sciences et Technologie, vol. 10, pp. 53-69, 2014.

[25] Z. Yin, Y. Wang, K. Wang, and C. Zhang, "The adsorption behavior of hydroxypropyl guar gum onto quartz sand," Journal of Molecular Liquids, vol. 258, pp. 10-17, 2018.

[26] B. V. Bahoria, D. K. Parbat, and P. B. Nagarnaik, "XRD Analysis of Natural sand, Quarry dust, waste plastic (ldpe) to be used as a fine aggregate in concrete," Materials Today: Proceedings, vol. 5, no. 1, pp. 1432-1438, 2018.

[27] C. Jiang, W. Guo, H. Chen, Y. Zhu, and C. Jin, "Effect of filler type and content on mechanical properties and microstructure of sand concrete made with superfine waste sand," Construction and Building Materials, vol. 192, pp. 442-449, 2018.

[28] A. Zalaghi, F. Lamchouri, H. Toufik, and M. Merzouki, "Valorization of natural porous materials in the treatment of leachate from the landfill uncontrolled city of Taza," Journal of Materials and Environmental Science, vol. 5, pp. 1643-1652, 2014.

[29] M. Benafqir, Z. Anfar, M. Abbaz et al., "Hematite-titaniferous sand as a new low-cost adsorbent for orthophosphates removal: adsorption, mechanism and Process Capability study," Environmental Technology \& Innovation, vol. 13, pp. 153-165, 2019.

[30] M. L. Mechri, S. Chihi, N. Mahdadi, and S. Beddiaf, "Study of heat effect on the composition of dunes sand of Ouargla (Algeria) using XRD and FTIR," Silicon, vol. 9, no. 6, pp. 933-941, 2017.

[31] M. L. Mechri, S. Chihi, N. Mahdadi, and S. Beddiaf, "Diagnosis of the heating effect on the electrical resistivity of Ouargla (Algeria) dunes sand using XRD patterns and FTIR spectra," Journal of African Earth Sciences, vol. 125, pp. 18-26, 2017.

[32] J. Liu, X. Zhu, H. Zhang, F. Wu, B. Wei, and Q. Chang, "Superhydrophobic coating on quartz sand filter media for oily wastewater filtration," Colloids and Surfaces A: Physicochemical and Engineering Aspects, vol. 553, pp. 509-514, 2018.

[33] C. Jia, Z. Wang, H. Liu, J. Bai, M. Chi, and Q. Wang, "Pyrolysis behavior of Indonesia oil sand by TG-FTIR and in a fixed bed reactor," Journal of Analytical and Applied Pyrolysis, vol. 114, pp. $250-255,2015$.

[34] M. Tiwari, T. D. Rathod, P. Y. Ajmal, R. C. Bhangare, and S. K. Sahu, "Distribution and characterization of microplastics in beach sand from three different Indian coastal environments," Marine Pollution Bulletin, vol. 140, pp. 262-273, 2019.

[35] P. Yuan, F. Annabi-Bergaya, Q. Tao et al., "A combined study by XRD, FTIR, TG and HRTEM on the structure of delaminated Fe-intercalated/pillared clay," Journal of Colloid and Interface Science, vol. 324, no. 1-2, pp. 142-149, 2008.

[36] N. Kouras, A. Harabi, F. Bouzerara et al., "Macro-porous ceramic supports for membranes prepared from quartz sand and calcite mixtures," Journal of the European Ceramic Society, vol. 37, no. 9, pp. 3159-3165, 2017.

[37] L. P. Lingamdinne, K. R. Vemula, Y.-Y. Chang, J.-K. Yang, R. R. Karri, and J. R. Koduru, "Process optimization and 
modeling of lead removal using iron oxide nanocomposites generated from bio-waste mass," Chemosphere, vol. 243, Article ID 125257, 2020.

[38] F. Sakr, A. Sennaoui, M. Elouardi, M. Tamimi, and A. Assabbane, "Étude de l'adsorption du Bleu de Méthylène sur un biomatériau à base de Cactus," Journal of Materials and Environmental Science, vol. 6, pp. 397-406, 2015.

[39] S. Guiza and M. Bagane, "Étude cinétique de l'adsorption du rouge de Congo sur une bentonite," Revue des sciences de l'eau, vol. 26, no. 1, pp. 39-50, 2013.

[40] S. Biswas and U. Mishra, "Continuous fixed-bed column study and adsorption modeling: removal of lead ion from aqueous solution by charcoal originated from chemical carbonization of rubber wood sawdust," Journal of Chemistry, vol. 2015, Article ID 907379, 9 pages, 2015.

[41] T. Sathvika, Manasi, V. Rajesh, and N. Rajesh, "Adsorption of chromium supported with various column modelling studies through the synergistic influence of Aspergillus and cellulose," Journal of Environmental Chemical Engineering, vol. 4, no. 3, pp. 3193-3204, 2016.

[42] R. Elmountassir, B. Bennani, Y. Miyah et al., "Microbiological and physicochemical characterization of hospital effluents before and after treatment with two types of sawdust," Journal of Chemistry, vol. 2019, Article ID 3275101, 10 pages, 2019.

[43] W. C. Tsai, M. D. G. De Luna, H. L. P. Bermillo-Arriesgado, C. M. Futalan, J. I. Colades, and M. W. Wan, "Competitive fixed-bed adsorption of $\mathrm{Pb}(\mathrm{II}), \mathrm{Cu}(\mathrm{II})$, and $\mathrm{Ni}(\mathrm{II})$ from aqueous solution using chitosan-coated bentonite," International Journal of Polymer Science, vol. 2016, Article ID 1608939, 11 pages, 2016. 